\title{
COULD A TRIREME TRANSPORTS WAR HORSES: THE MISUNDERSTANDING BEHIND THE INTERPRETATION OF THE ANCIENT GREEK TERM IППАГ ГГА "HIPPAGOGA".
}

\begin{abstract}

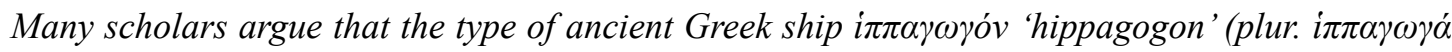
'hippagoga'), during the Classic period, was nothing more than the result of a modified old trireme and that any effort to determine the design of this specific type of vessel has been based solely on this conclusion. However, even if convertible, could a trireme have transported horses? Where is such a testimony written in ancient texts and how could translation possibly disorient a researcher?
\end{abstract}

This paper attempts to shed new light on all the above mentioned potential issues.

KEYWORDS: ANCIENT GREEK SHIPS, HORSE TRANSPORTATION BY SEA, HIPPAGOGON, "IППАГ ГГОN".

\section{THE NECESSITY FOR BUILDING A NEW CLASS OF SHIP FOR TRANSFERRING WAR HORSES}

The transport of just riders and cavalry was one of the most important operational necessities of the landing operations of the ancient Greeks. The construction of 'hippagogon'1 was a substantial technological development in the shipbuilding of the day and was developed according to the requirements of the military conflicts of the time. However, due to limited use and the fact that the operation of the 'hippagogon' vessels presented technological difficulties, several problems arose at the tactical level.

The 'i $\pi \pi \alpha \gamma \omega \gamma o ́ v$ ' during the Classic and Hellenistic period could not disembark armoured equestrian units ready to enter into battle. She was only able to carry individual groups of riders or

1 i $\pi \pi \alpha \gamma \omega \gamma o$ derives from the ancient Greek words: i $\pi \pi \mathrm{s}$ (horse) $+\not \alpha \gamma \omega$ (to conduct, to drive). Also i $\pi \pi \eta \gamma \omega \gamma o ́$ or i $\pi \pi \eta \gamma o ́$ (Stamatakos, 1999: p. 471, Ioannidou, 2014: 94). an extremely limited number of war horses. This limitation removed from the attacker, inter alia, the possibility of mounting a surprise attack on the battlefield.Generally, the 'hippagogon' causes great interest both because it is related to the difficult task of transporting war horses and secondly because there is a great lack of sufficient details concerning its construction and operation.

\section{THE FIRST WRITTEN REFERENCES OF THE TERM}

The first written mention of the term i $\pi \pi \alpha \gamma \omega \gamma \alpha$ ' "hippagoga" comes from Herodotus. In his sixth book we read about a programme of the construction of naval ships that included 'hippagoga'. That programme was ordered by the king of Persia, Darius, to the Greek City States, which were tributaries of the Persian Empire (Herodotus: 6, 48).

The same type of ship is again mentioned with 


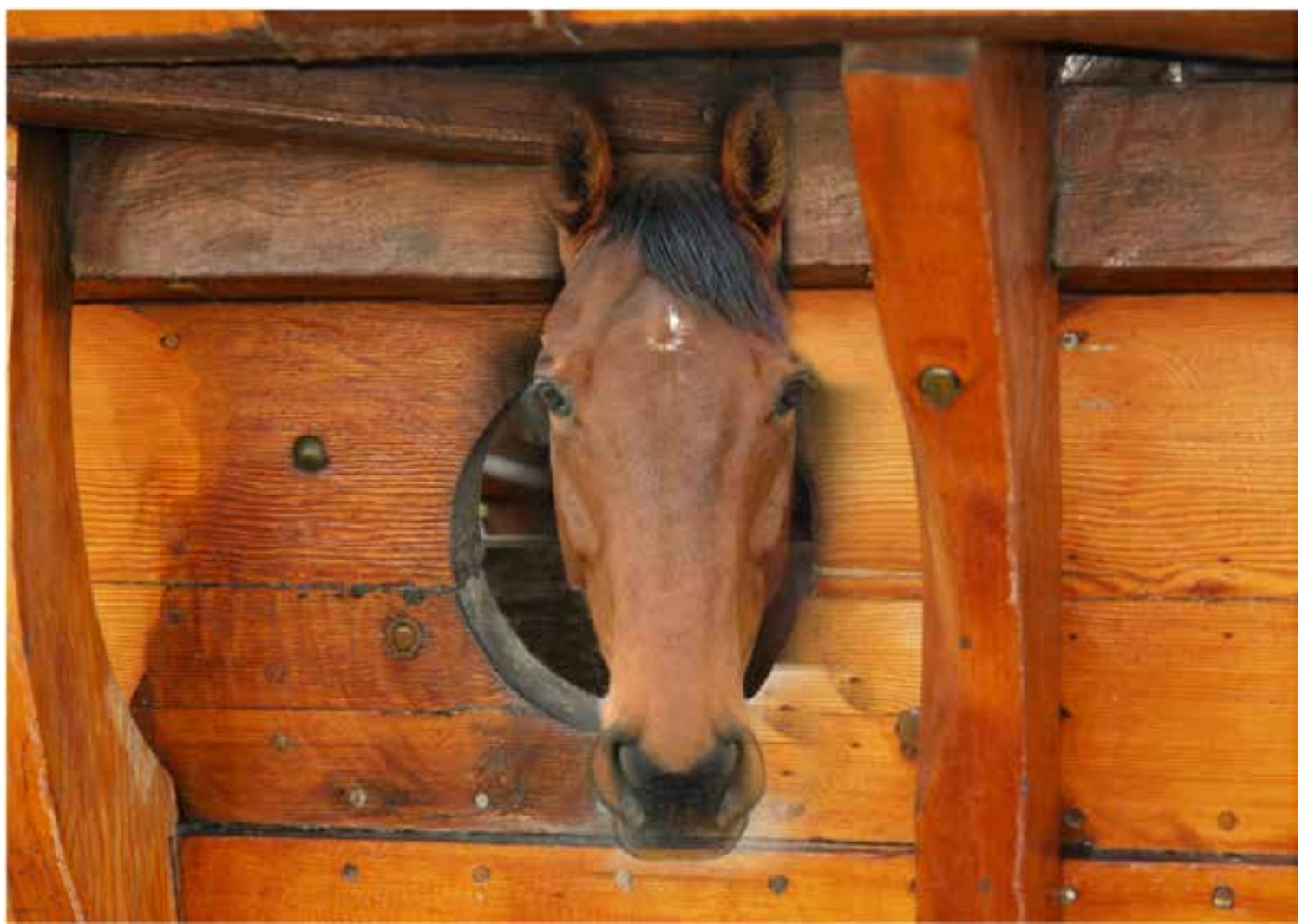

Fig. 1 Could a trireme transports war horses; humorous collage-photo from Christy E. Ioannidou.

regard the campaign against Greece led by Xerxes, but unfortunately with no additional information:

[Besides the triremes, there was an assemblage of thirty-oared and fifty-oared galleys, of cercuri, and transports for conveying horses, amounting in all to three thousand].

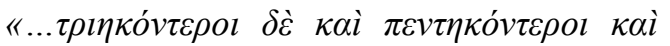

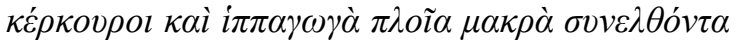

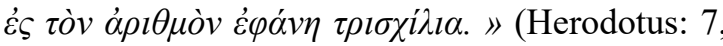
97).

Later, during the Peloponnesian War (431 BC$404 \mathrm{BC})$, the $i \pi \pi \alpha \gamma \omega \gamma \alpha$ were mentioned again, about which Thucydides mentions it was first built in Greece at that time.

[...and three hundred cavalry in horse transports, and then for the first time made out of old galleys; ]

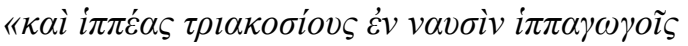

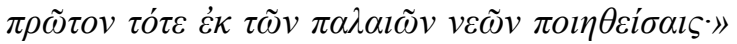

(Thucydides: 2, 56).

During the Sicilian expedition (415-413 BC), Athens sent the Athenian fleet to Syracuse originally with a "hippagogo", carrying 30 riders:

[... and one horse-transport carrying thirty riders.].

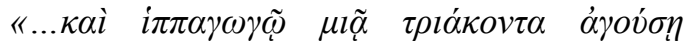
$i \pi \pi \varepsilon ́ \alpha \varsigma »$ (Thucydides: 6, 43).

\section{APPROACHING THE TEXTS}

When studying the first text of Thucydides (2, 56), it is quite obvious that there is no mention of a modified trireme or, generally, of any warship. As many people are aware, the word vaṽ 'nafs' has the general meaning of a ship. It might, therefore, be any type of vessel, such as a sailing ship (like a cargo ship), for example, or a galley (like a pentecontor). In earlier times, there was a dis- 


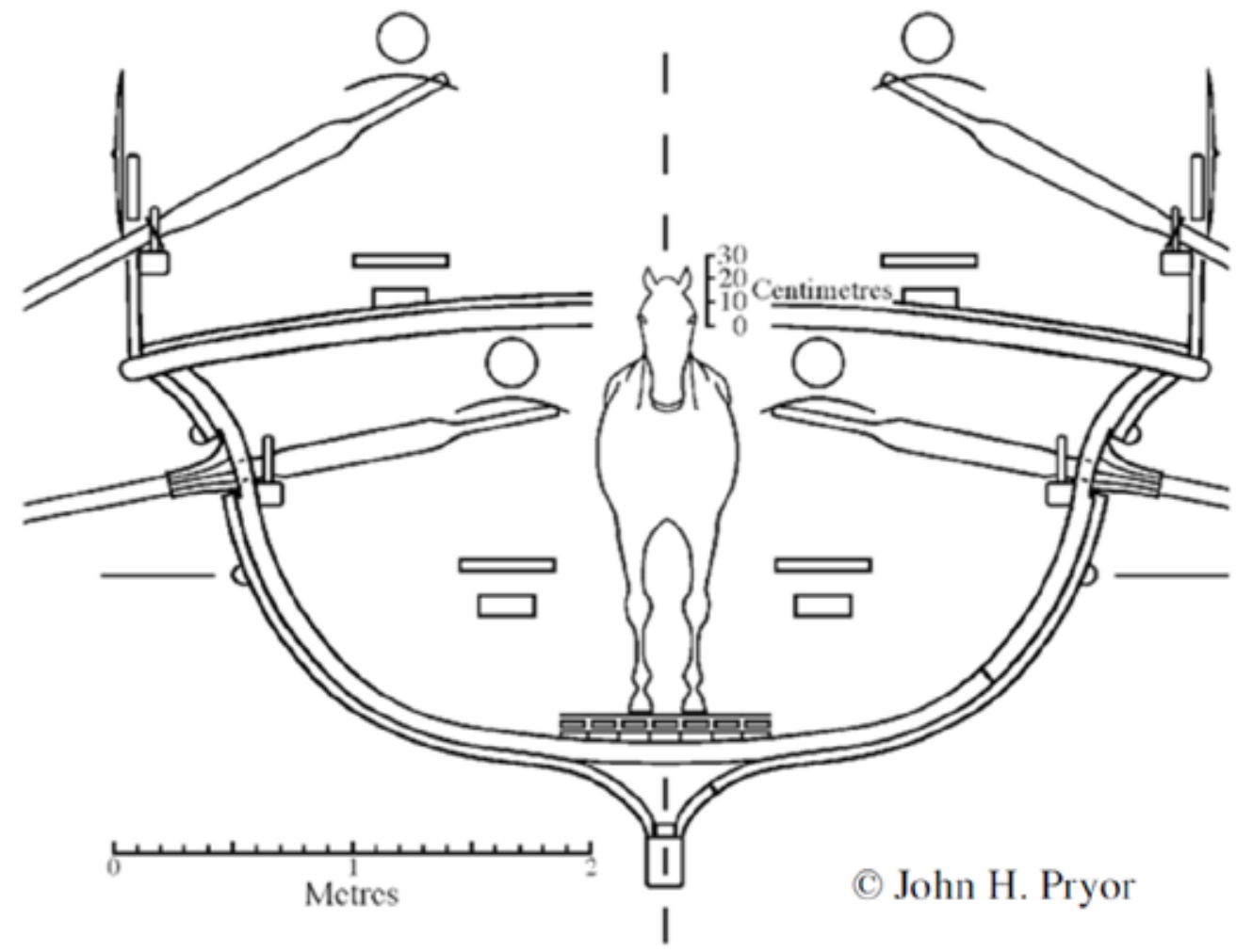

Fig. 2 Horse transport of the era of Macedonian Emperors I: Standard bireme dromon with a fifteen-hand horse. (Illustration by John H. Pryor. Pryor, J.H. - E.M. Jeffreys, 2006, 321).

tinction made by using the word long $\mu \alpha \kappa \rho \alpha \imath \nu \eta \alpha$

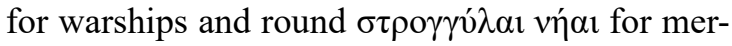
chant ships. If the converted vessel originated as a specific type of ship, i.e. a trireme, Thucydides would surely have mentioned this fact. Could it be that a misunderstanding appeared in later Greek translations?

As mentioned above, in the ancient text we see " $\pi \alpha \lambda \alpha \iota \omega ́ v v \varepsilon \dot{v} v$ ", which means old ships (any type of an old ship). The first person to translate Thucydides from the ancient text into pre contempory Greek was Neofytos Doukas, in 1805. In his translation of the second book of Thucydides (paragraph 56), it becomes clear that "hippagoga" were, indeed, converted old ships:

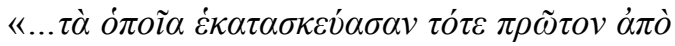

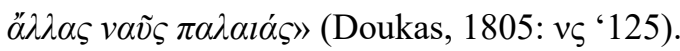

In 1940, Thucydides was first published in modern Greek by the Oxford University Press. The translation was done by Elefthérios K. Venizélos, the Prime Minister of Greece, serving from 1910-
1915, 1917-1920, and 1928-1933. In this edition, Venizelos was also the first to translate " $\pi \alpha \lambda \alpha 1 \omega$ v veஸ́v" as "old war ships". By adding the word 'war' in front of the word 'ship' he completely changed the meaning, as he encourages readers to think more about triremes, less about any other warship (pentekontors or triakontors, for example) and not at all about any other type of vessel. It is not difficult to see how people who are unfamiliar with ancient texts adopted the translation of Venizelos and, as time passed, to copy this information or to translate 'war ships' directly as 'triremes'.

The question remains as to what happen before 1940 with the English translations?

The first translation ever from the ancient Greek text was by the Italian humanist, rhetorician, and educator Lorenzo Valla (1452 - 1483). Valla translated Thucydides into Latin. In the 1538 edition of his translation we read that "hippapoga" were constructed from old vessels, given that the Latin word "navis" has the general mean- 


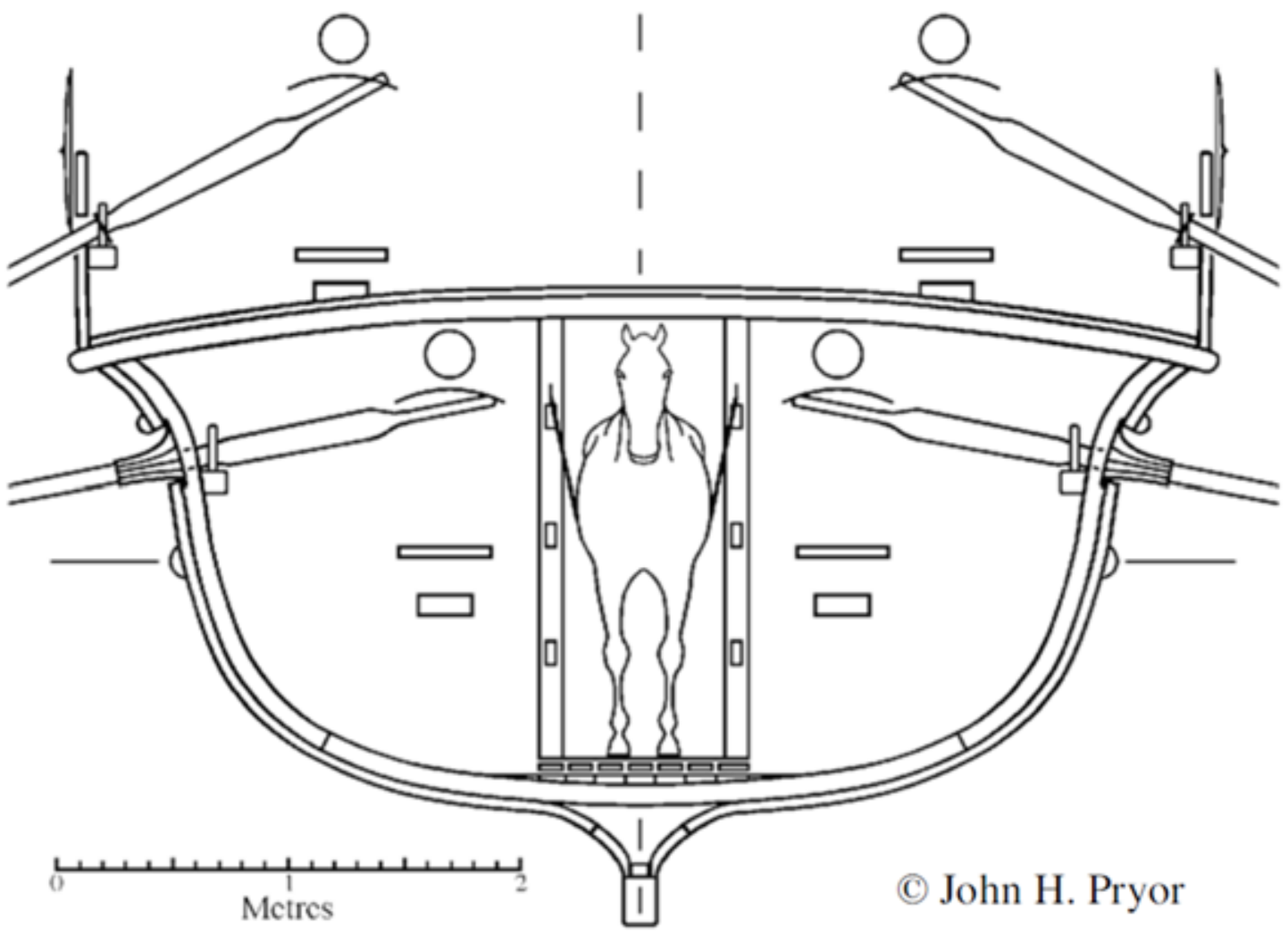

Fig. 3 Horse transport of the era of Macedonian Emperors II: Modified dromon/chelandion with a fifteen-hand horse. (Illustration by John H. Pryor. Pryor, J.H. - E.M. Jeffreys, 2006, 323).

ing of ship: “...trecentos equites in hippaginibus, quas tunc primùm ex vetustis nauigiis fecerant" (Valla, 1538: 136).

The first translation from ancient Greek to English was rendered by the English philosopher Thomas Hobbes, in 1628-9. Hobbes, out of deference to the ancient Greek historian, gave the meaning by using the word "vessel", keeping the generally meaning of any type of ship:

"...In these galleys he had four thousand men of arms; and in vessels then purposely first made to carry horses, three hundred riders" [Hobbes].

It seams that for hundreds of years similar translations were preserved until the arrival of an opposing opinion. In 1829, S.T. Bloomfield opposed the opinion of Hobbes by translating "the old vessels" as "old galleys" and provided a footnote: "Hobbes wrongly renders, 'vessels then purposely made" "without any further explanation as to why Hobbes made, according to his contention, such a mistake (Bloomfield, 1829: 428). From this point, it was easy for scholars to either oppose or to agree with Bloomfield's point of view. By using the word 'gallie' (galley) he changed the reference to warships. From there it was only a small step for everyone to reach to the conclusion that these ships were triremes.

It would be quite easy for somebody to become confused after searching the texts. There is, although, a slight distinction between nafs ( $v \alpha \tilde{v} \varsigma$ ) for a warship and ploion ( $\pi \lambda$ oĩov) for general use (including warships). Thucydides, in one part, distinguishes these two types of ships (Thucydides: 4, 116). However, in Diodorus, about the term ippigos nafs (i $i \pi \eta \gamma$ ò $\varsigma \alpha \tilde{u} \varsigma$ ) is used for a part of the fleet but for all ships of the fleet (including $i \pi \pi \eta \gamma o ̀ \varsigma$ vaṽ $\varsigma$ ) the general term $\pi \lambda$ oĩov is used.

[...and he had the transports for men and horses follow, towed by the ships that used oarsmen; and last of all came also the cargo-ships of the pi- 


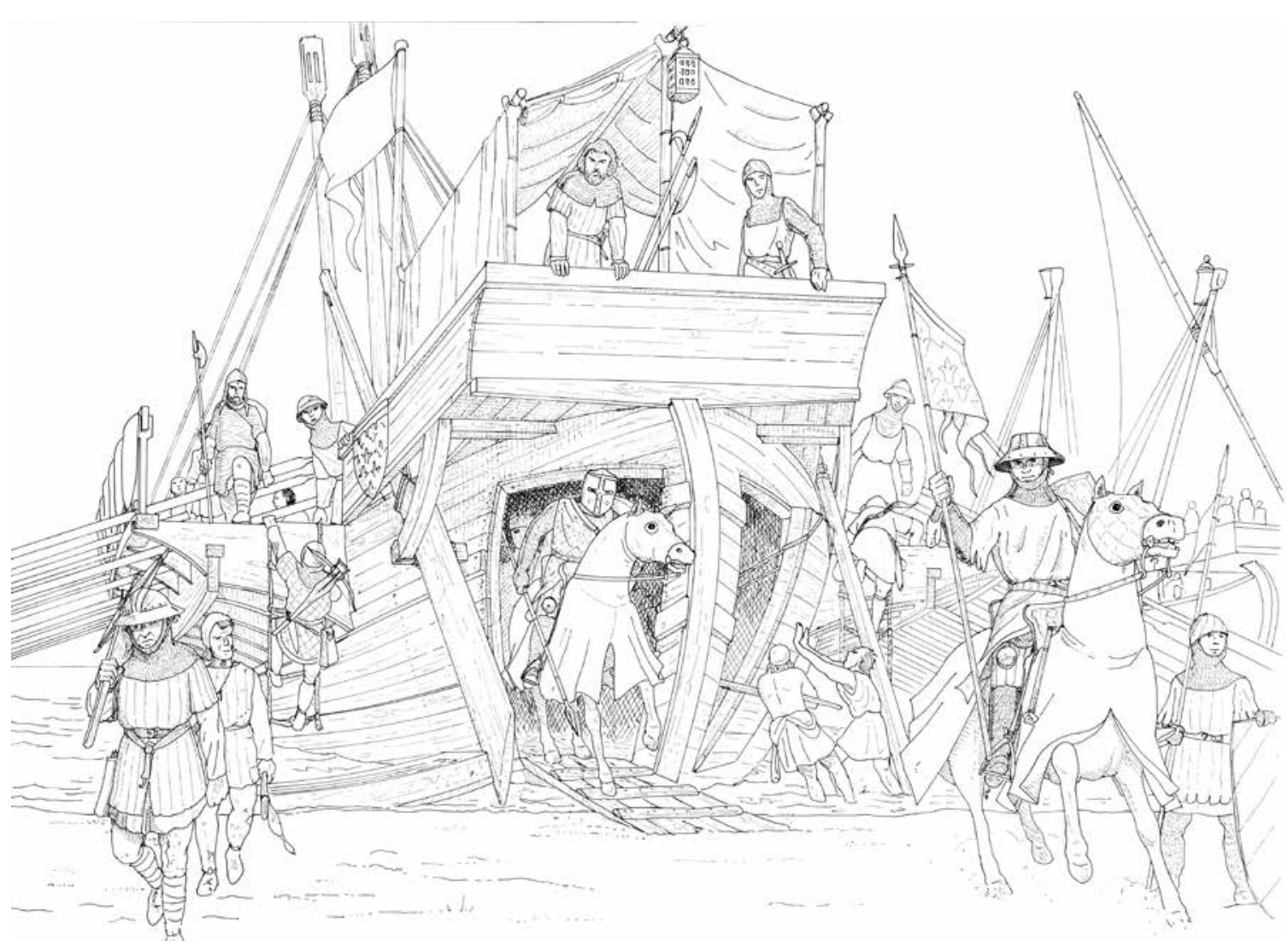

Fig. 4 Artistic representation of a 13th century horse-transportation galley (tarida).

(Illustration by Yannis Nakas).

rates and of the merchants and traders, which as we have already said, were exceedingly numerous, so that the whole space between the island and the opposite shore was seen to be filled with his vessels, which brought great fear and panic to those who were watching from the city].

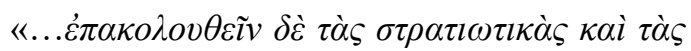

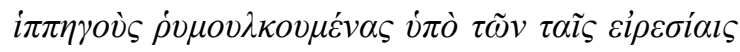

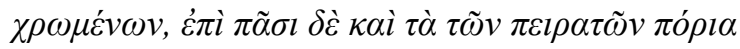

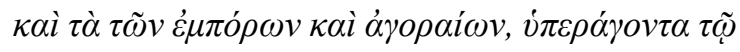

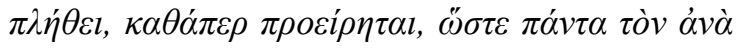

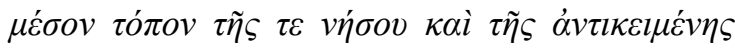

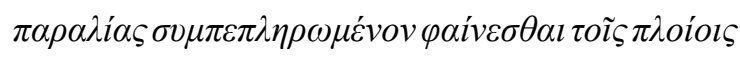

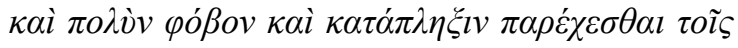

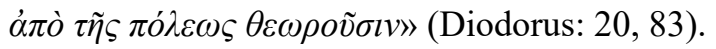

The term ippigos nafs (i $\pi \pi \eta \gamma o ̀ \varsigma$ vaṽ $)$ was also used by Polybios (Plb: 1.27.9), while in ancient inscriptions from the 4th century BC we read about ippigos (i $\pi \pi \eta \gamma o ̀ s$ ) and the names of that

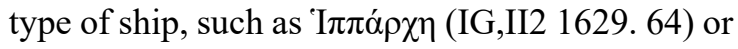

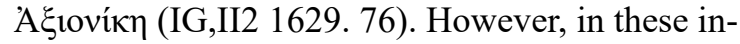
scriptions it is clearly understood that these ships are not triremes as the term "trireme ippigos"

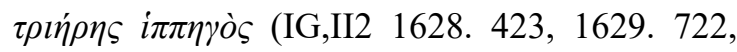
944) exists for them. From the above it can be assumed that ippagogo could be any kind of ship and, in the case of trireme, there is often a further

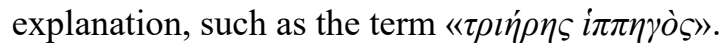

\section{CARRYING HORSES OR RIDERS?}

In the first text of Thucydides $(2,56)$ it is not altogether if "hippagoga" simultaneously transferred horses and riders, but in the text at 6,43 it is quite obvious that ippagoga transported only riders $(i \pi \pi \varepsilon \dot{\alpha} \alpha \varsigma>i \pi \pi \varepsilon \tilde{c} \varsigma=$ horseman/riders). However, a mistranslation could potentially have big implications, but more often than not it leads to an awkward translation that makes no sense or trans- 
forms a historical fact. For example, Bloomfield, in his book published in 1829, translated into English the phrase $\tau \rho l \alpha \dot{\alpha} о v \tau \alpha$ i $i \pi \varepsilon \dot{\alpha} \alpha$, as "thirty cavalry" which means soldiers or warriors who fight mounted on horseback, instead of "thirty riders" or "thirty horsemen" which is the correct translation (Bloomfield, S.T., 1829: 78).

Next followed Rev Henry Dale who, in his book "The history of the Peloponnesian war", published in 1873, wrote "thirty horses" (Dale, 1873: 407), as did Richard Crawley (Crawley, 1914: 432), while Benjamin Jowett wrote "thirty horsemen and horses" (Jowett, 1881: 440). The same mistake was repeated by others, including some Greek authors who failed to check the ancient text but, instead, blindly followed the English mistranslation.

If we read further Thucydides texts we are surprised by the apocalypse that "hippagoga" at that time only carrying riders.

In the speech by Athenagoras of Syracuse to the Syracusan Assembly, it becomes clear that the Athenians sent "hippagoga" but without horses as they were sure these would be obtained in their allied cities of Sicily like Egesta:

[I know that they will not have horses with them, or get any here, except a few perhaps from the Egestaeans].

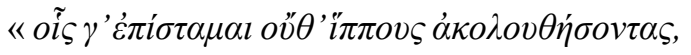

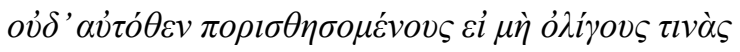

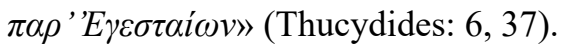

Indeed, at the beginning of the Sicilian Expedition, the Athenians faced serious operational problems because they lacked the cavalry that their rivals had. For this reason, during the winter of 415-14 BC they sent a letter to Athens, demanding more money and cavalry. Athens' response to the urgent request was to send two hundred and fifty riders with their equipment, but without their horses for the reasons mentioned above:

[Upon their return to Catana they found the riders arrived from Athens, to the number of two hundred and fifty (with their equipment, but without their horses which were to be procured upon the spot), and thirty mounted archers and three hundred talents of silver].

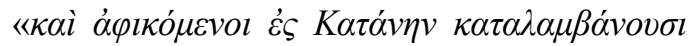

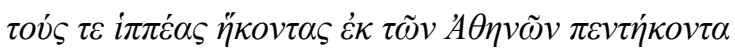

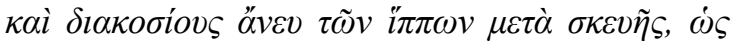

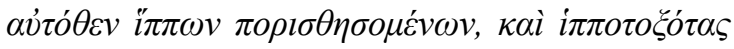

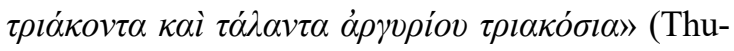
cydides: 6,94$)$.

So far, it is clear that nowhere does there appear any reference to converted triremes or horse transportation by open sea. The Athenians did not actually attempt to transport war horses by the sea all the way to Sicily. Strange though it may appear, the reason is simple. They did not have the capability to do so (Pryor-Jeffreys, 2006: 305). The appearance of the term "hippagogo trireme" in ancient texts leads to the explanation that the specific trireme was capable of carrying only horse riders, as Demosthenes underlines:

[...In addition, you must prepare transport (hippagogous triremes) for half our horsemen, and a sufficient number of boats].

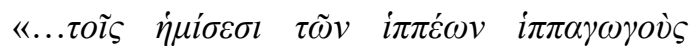

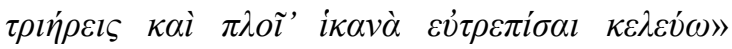
(Demosthenes/Philippic 1.16).

\section{THE PROBLEM OF TRANSPORTING HORSES BY SEA}

Horse transportation by i $\pi \pi \alpha \gamma \omega \gamma \alpha$, at that time, was possibly undertaken with an extremely limited number of horses and exclusively on short coastal routes. John H. Pryor offers an interesting analysis of i $\pi \pi \alpha \gamma \omega \gamma \alpha$ in Macedonian in the medieval period, mentioning the problems that could have occurred with such transportation (Pryor, J.H. - E.M. Jeffreys, 2006). The transport of war horses by ship requires a series of studies to achieve the safe construction of such a vessel. Here, for example, are some points that should be seriously taken into consideration when an old ship is to be converted into a 'hippagogo':

a) The weight of the horses, riders and acces- 
sories in relation to the new draft and the ship's stability.

The size and weight of horses differs according to breed. Light (small) horses for horse riding usually weigh between 380 and $550 \mathrm{~kg}$ (Bongianni, 1988: entry 1, 68, 69) while large ones 500-600 kg (Bongianni, 1988: entry 12, 30, 31, 32, 75). Pryor mentions that a medieval warhorse weighed around $650 \mathrm{~kg}$. (Pryor, 2004: 116). The common Greek Thessaly horses of today are around $1.40 \mathrm{~m}$ tall and weigh between 350 and $450 \mathrm{~kg}$.

b) Bays and oar holes (if dealing with triremes) need to be watertight.

c) The minimum safe distance between horses.

d) The minimum safe distance between horses and oarsmen. It is better that they are separated and if possible without visibility of the oarsmen in order to avoid injury to the oarsmen or themselves, or to be panicked and cause chaos on the vessel.

e) The increase in the strength of the superstructure, if necessary.

The additional weight should not significantly affect the speed. To prevent accidents and the risk of the ship capsizing, special attention is required to maintain calm on board and vessel stability so that skittish horses do not become excessively agitated during the voyage.

In addition, food and water storage are of great importance. In Pryor's analysis we derive the information that during the summer months, a horse would consume 8 gallons (36 litres) of water daily (Pryor-Jeffreys, 2006: 327). One of the first reports of a Byzantine 'hippagogon' comes from Theophanes the Confessor. He wrote that Constantine V, in 763 A.D., had, among others, a fleet of 800 'chelandia' for his campaign against the

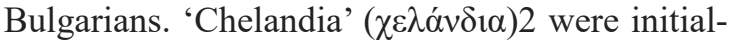
ly commercial vessels which were later construct-

2 The term Chelandion is derived from the Greek word

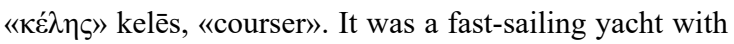
one bank of oars, Hdt.8.94, Th.4.9, 8.38, X.HG1.6.36, Ephipp.5.17 (anap.), Plb.5.94.8, Plin. HN7.208, etc. The Chelandion first appeared during the early $8^{\text {th }}$ century (Pryor-Jeffreys 2006, 166-169). ed as auxiliary vessels for fleets for transporting mainly soldiers. The 'chelandia' of Constantine $\mathrm{V}$ carried 12 horses each:

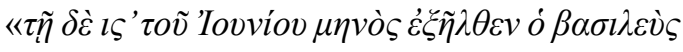

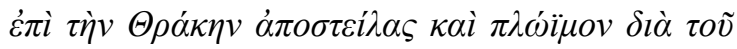

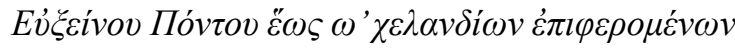
$\dot{\alpha} v \dot{\alpha} \quad \imath \beta$ ' i $\pi \pi \omega v »$ (Theophanes, Chronographia, A.M. 6254 (vol. 1, 432-3).

As a rough calculation regarding the drinking water consumption of horses using the text above, it can be concluded that the 12 horses of a 'chelandion' would have consumed about 432 litres of water a day. For a voyage, for example, of four days, they would have consumed around 1.73 tons of water (Pryor-Jeffreys, 2006: 329).

Another important factor was the construction of a small platform that a horse could stand on without hurting its legs, which it otherwise would if standing directly on the floor of the ship, and a system of drainage ports, which the dung and the urine would be thrown overboard through (Hayes, 1902: 195). One could assume that for hygiene reasons a horse could not stay for a long on a floor covered in dung and urine.

The above leads to the following conclusions:

Could a trireme (which was narrow, light and often had to come ashore to dry its timbers) be modified to a 'hippagogo' for horse transportation? Anyone who has visited the trireme "Olympias" in Faliro Bay, Greece, can imagine the difficulties with such a ship carrying horses, especially as many as thirty as some translators have written. A 'Hippagogo' requires a different kind of shipbuilding timber and construction in order to be capable of withstanding the weight of the horse, the weight of the minimum quantities of water and food and also to be able to be at sea for long periods.

The large quantities of water and food could be carried by accompanying cargo ships. However, inside a 'trireme-hippagogo' there would have been a requirement for a minimum quantity of clean drinking water to cover the expected number of hours at sea. This would certainly have created some difficulties. 
In addition to coastal and short-haul travel, it is unclear if any longer equine transport trips were made by these vessels further offshore.

During Alexander the Great's campaign in India (327-326 BC) there is a reference to horse transport vessels constructed specifically for this purpose. The horses were visible from shore, which leads to the conclusion that they were placed on the decks (or at least some of them were).

[The horses which were visible on the decks of the transports struck the barbarians who saw them with such surprise that those of them who were present at the starting of the fleet accompanied it a long way from the place of embarkation. For horses had never before been seen on board ships in the country of India].

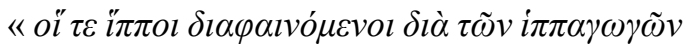

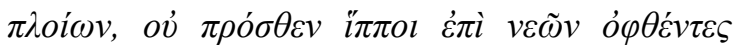

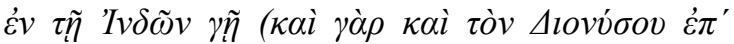

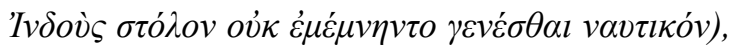

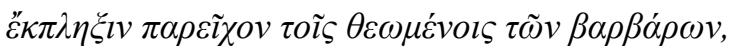

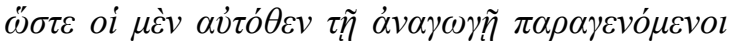

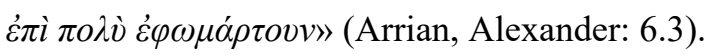

Undoubtedly, these 'hippagoga' were not converted triremes, but ships that, from the beginning were designed and built to withstand the weight and the specificity of transporting war horses. This interpretation is supported by the fact that in the occupation of Tyre (332 BC) hippagoga were used that carried heavy siege engines (Arrian, Alexander: 2.21).

The use of 'hippagogon' continued with other forces that competed for supremacy in the Mediterranean (such as the Romans who, during the First Punic War (264-241 BC), brought 'hippagoga' by means of towing (Polybios: 1. 26-28). However, there appear to be no further insights regarding their use, beyond what we have already covered.

Despite the development of warships and the need to carry more horses and riders, the process of their usage (by that time) remained the same. The horses were landed carefully down ramps and thereupon the riders rode them to join the battle. The disembarkation of mounted riders began to appear in 960 AD, when Nikephoros Phokas took over as head of the campaign for the liberation of Crete from the Saracens. According to the testimony of the Byzantine historian and chronicler Leo the Deacon, Nikephoros Phokas, who had distinguished experience in naval projects, disembarked a fully armed and mounted army directly from the sea to the land:

[Accordingly, Nikephoros, upon the order of the emperor, mustered the army of Asia and embarked them on ships, and after a swift voyage he also brought up a large number of fire-bearing triremes (the Romans call these dromones) to anchor at Crete. When it seemed to be an opportune moment for disembarkation, he displayed in deed the experience that he had in military affairs. For he had brought ramps with him on the transport ships, which he set up on the beach, and thus transferred the army, fully armed and mounted, from the sea on to dry land].

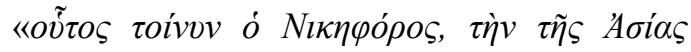

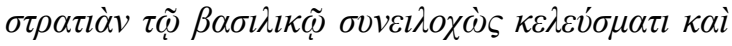

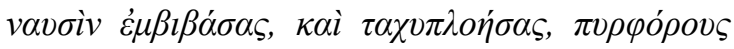

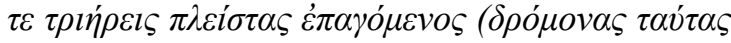

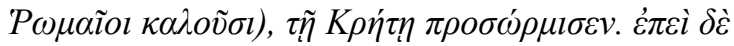

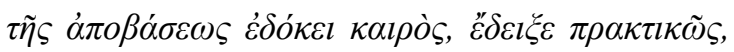

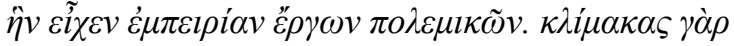

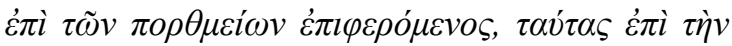

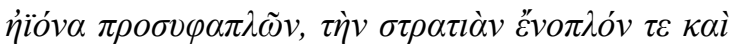

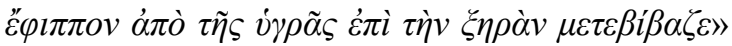
(Leo the Deacon, Historiae: 1.3).

It is quite remarkable that Leo referred to the ships of the Phokas fleet using the classical term 'fire-bearing triremes'. As he explains, these triremes were dromons. One might well doubt that explanation, but it has to be said that some writers until the $13^{\text {th }}$ and $14^{\text {th }}$ century referred to dromons as 'triremes', perhaps as a result of the dominant tendency of classicism, or because of the three oarsmen per oar, like the 'alla sensile' oarage system on galea. It is undeniable that it can not be a reference to a galley ship with the construction and the limitations of the triremes of the $5^{\text {th }}$ century BC. 


\section{CONCLUSIONS}

Bearing all the above mentioned in mind, one can reach the conclusion that the 'i $\pi \pi \alpha \gamma \omega \gamma \alpha$ ' of Classic Greece were converted older ships and later some of them were triremes. These ships transported mainly riders or a very small number of horses but, as "hippagoga triremes", carried only riders. It defies logic that a "trireme hippagogon" or any "hippagogon" of that period could carry from Athens to Corcyra and on to Sicily the thirty horses that some have assumed, probably as a result of a mistranslation. Later, during the Hellenistic period ships were built that were designed exclusively for horse transportation, but these ships sailed close to the shore or were only able to travel a relatively short distance. Information concerning the "hippagoga" being capable of traveling in the open sea with mounted riders is draw mostly from the 10th century AD.

Subsequently, Venice, and then other Western powers, developed the ability to transport horses for long distances for the Crusades, using both sailboats and galleys. With the construction of 'tarides' (12th century AD) the direct disembarkation of large number of troops on horseback became possible (Pryor, 2004: 107).

$$
* * *
$$

Arheologija i prirodne nauke (Archaeology and Science) is an Open Access Journal. All articles can be downloaded free of charge and used in accordance with the licence Creative Commons - Attribution-NonCommercial-NoDerivs 3.0 Serbia (https://creativecommons.org/licenses/bync-nd/3.0/rs/.

Časopis Arheologija i prirodne nauke je dostupan u režimu otvorenog pristupa. Članci objavljeni u časopisu mogu se besplatno preuzeti sa sajta i koristiti u skladu sa licencom Creative Commons - Autorstvo-Nekomercijalno-Bez prerada 3.0 Srbija (https://creativecommons.org/licenses/bync-nd/3.0/rs/.

\section{BIBLIOGRAPHY}

\author{
Bloomfield, S.T. 1829
}

The History of Thucydides, London: Longman.

\section{Bongianni, M. 1988}

Simon \& Schuster's Guide to Horses \& Ponies of the World, New York: Fireside Book, Simon \& Schuster's.

\section{Crawley, R. 1914}

History of the Peloponnesian War, done into English, London: J\&M Dent \& Sons Ltd.

\section{Dale, H. 1873}

The history of the Peloponnesian war, New York: Harper \& brothers.

\section{Hayes, H. 1902}

Horses on Board Ship, A Guide to Their Management, London, Hurst and Blackett, Limited.

\section{Hobbes, T. 1839}

Thucydides, The English Works of Thomas Hobbes, (Thucydides' Peloponnesian War), vol. 8, Part I.

Ioannidou, Ch. E. 2014

Dictionary of Ancient Greek Naval Terms [in

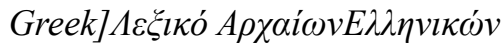

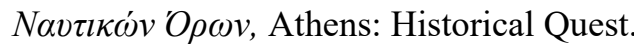

\section{Ioannidou, Ch. E. 2016}

Trireme. Tactics and Operational Environment in

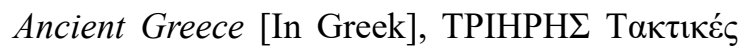

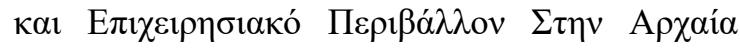
E $\lambda \lambda \alpha \dot{\alpha} \delta \alpha$, Athens: Naval History Department/Hellenic Navy.

\section{Jowett, B. 1881}

Thucydides, (translated into English), Oxford: Clarendon Press. 
Pryor, J. H. 2004

From Dromon to Galea: Mediterranean bireme galleys $A D$ 500-1300, in: Robert Gardiner \& J. S. Morrison (eds.), The Age of the Galley: Mediterranean Oared Vessels Since Pre-Classical Times. Conway's History of the Ship, Annapolis: Naval Institute Press.

Pryor, J. H. and Jeffreys, E. M. 2006

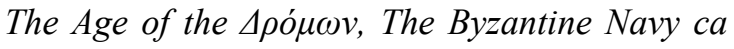
500-1204, Leiden: Koninklijke Brill NV, The Netherlands Koninklijke Brill NV incorporates the imprints Brill Academic Publishers, Martinus Nijhoff Publishers and VSP.

Rawlinson, G. 1910

History of Herodotus

Sullivan, F. D. and Talbot, A.-M. (intr. trans. annot) 2005

The History of Leo the Deacon: Byzantine Military Expansion in the Tenth Century,

Dumbarton Oaks Papers.

\section{Stamatakos, 1999}

Dictionary of Ancient Greek Language, [in Greek]

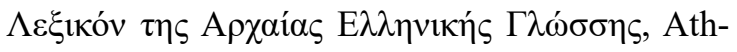
ens: Vivliopromitheftiki.

\section{Theophanes,}

Chronographia, A.M. 6254, vol. 1: 432-3.

Valla, Lorenzo, 1407-1457

Thucididis Historiarum liber a Laure[n]tio Vallensi traductus ([entre 1450 i 1499]).

Libro manuscrito Universitat de València. Biblioteca Històrica.

\section{REZIME \\ MOŽE LI TRIREMA DA \\ PREVOZI KONJE U RATNIM \\ POHODIMA: NESUGLASICE \\ OKO INTERPRETACIJE \\ STAROGRČKOG IZRAZA \\ 'IIПАГЛГОN I "HIPPAGOGON"}

\section{KLJUČNE REČI: GRČKI BRODOVI, TRANS- PORT KONJA MOREM, "HIPPAGOGON"

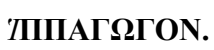

Mnogi naučnici smatraju da je tip grčkog broda $1 \pi \pi \alpha \gamma \omega \gamma o v$ 'hippagogon' (plur. I $\pi \pi \alpha \gamma \omega \gamma \alpha$ 'hippagoga') tokom klasičnog perioda bio ništa drugo do rezultat modifikovane stare trireme $\mathrm{i}$ da je bilo kakav napor da se utvrdi izgled ovog specifičnog tipa plovila zasnovan još uvek na pretpostavkama. Među istraživačima se postavlja pitanje, može li trirema prevoziti konje? Gde je takvo svedočenje zapisano u starim rukopisima $\mathrm{i}$ da li bi prevod mogao da donese odgovor na ovo pitanje ili možda još više zbuni istraživače. 